\title{
A QUANTITATIVE INVESTIGATION INTO SCAVENGING OF AIRBORNE SEA SALT OVER MACQUARIE ISLAND
}

\author{
by Michael Mallis
}

(with ten tables and two text-figures)

MALLIS, M., 1988 (viii): A quantitative investigation into scavenging of airborne sea salt over Macquarie Island. Pap. Proc. R. Soc. Tasm., 122(1): 121-128. Paper presented at the Macquarie Island Symposium, Hobart, May 1987. https://doi.org/10.26749/rstpp.122.1.121 ISSN 0080-4703. Physics Department, La Trobe University, Bundoora, Victoria, Australia 3083.

Through study of rainwater collections made at Macquarie Island, during the 1985-86 austral summer, it was possible tocompare previous theoretical predictions of sea-salt scavenging in precipitation with actual observations. Some earlier rainwater collections are found to have grossly overestimated the initial salt budget. It is shown that the earlier theoretical investigation adequately accounts for the salt budget and that sea-spray droplets play little part in salt scavenging by precipitation over most parts of the island.

Key Words: sea salt, salt scavenging, Macquarie Island.

\section{INTRODUCTION}

Calculations, based on actual rainwater measurements obtained from Evans (1970) and Jenkin (1972), led to the conclusion that in- and below-cloud scavenging processes, due to solid seasalt particles, could only account for part of the observed total salt $(\mathrm{NaCl})$ budget over Macquarie Island, the balance being due to sea-spray droplets (Mallis 1985). Subsequently, rainwater collections were performed, from December 1985 to April 1986 inclusive, for various sites over the island. Chemical analysis of chlorides and sulphates tends to support previous theoretical predictions (Mallis 1985) and reject Evans'data; Jenkin's data are also found to be suspect, though to a lesser degree. It can be demonstrated that it is possible to account for the expected salt budget without having to make up the difference by resorting to sea spray.

Even though drastic simplifications and parameterisations have been made in order to simplify the theory, they do make problems more tractable. This report follows up earlier work in this field and provides quantitative data to support previous theoretical predictions.

\section{PROCEDURE}

The experimental procedure for collecting water samples is described below. In all, four sites were chosen as representative of anticipated different conditions to be encountered over the island and within easy access of the Australian Nationa Antarctic Research Expedition (ANARE) station. Table I lists these sites, together with their approximate altitudes and commissioning dates. Site 1 was located in the Bureau of Meteorology

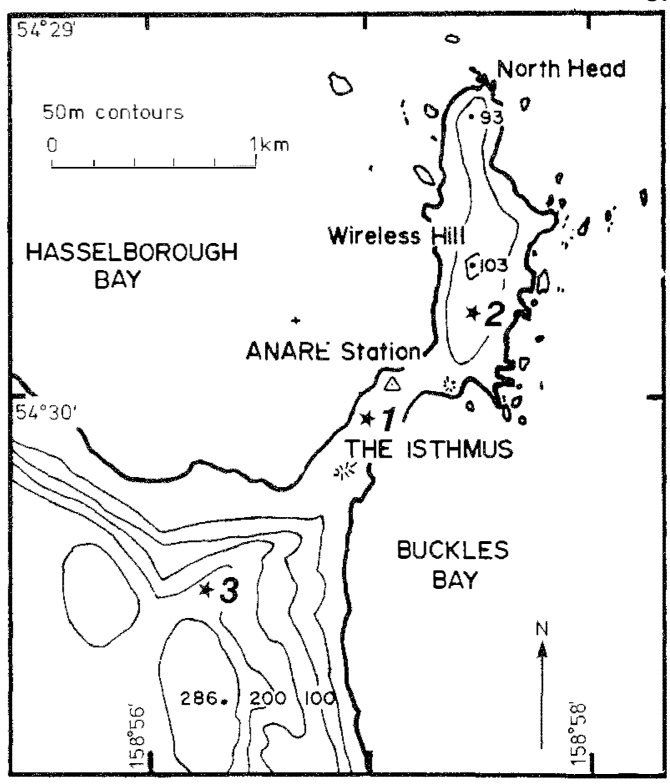

FIG. I - Map of the isthmus and its immediate environ, with approximate positions of rainwater collection sites 1, 2 and 3. Site 4 is located about 3 $\mathrm{km}$ south of site 3 . 
TABLE 1

Water collection site details

\begin{tabular}{lccc}
$\begin{array}{c}\text { Site } \\
\text { name }\end{array}$ & $\begin{array}{c}\text { Site } \\
\text { number }\end{array}$ & $\begin{array}{c}\text { Commissioning } \\
\text { date }\end{array}$ & $\begin{array}{c}\text { Altitude } \\
(\mathbf{m})\end{array}$ \\
\hline Isthmus & 1 & 13 Dec 1985 & 4 \\
Wireless Hill & 2 & 18 Dec 1985 & $\sim 100$ \\
Ski Hut & 3 & 29 Dec 1985 & $\sim 220$ \\
Mt Eld er & 4 & 23 Feb 1986 & $\sim 300$ \\
\hline
\end{tabular}

Instrument Enclosure on the isthmus; site 2 was atop W ireless Hill, located near Lambing Gully, which also afforded some protection from direct wind gusts; site 3 was situated near North Mountain and close to the ski hut (see fig. 1). Site 4 was located on the plateau proper, at the base of $\mathrm{Mt}$ Elder on the western side. As only three collection containers were in use, sites 3 and 4 were alternated Sites 2 and 3 approximate very closely to those originally chosen by Jenkin (1972); site 1 is, of course, identical. However, the sampling procedure adopted for this study differs from that used by Evans (1970) and Jenkin (1972) to the point where it is concluded that spurious results were originally obtained. This discrepancy is discussed further later.

Before each collection container (a plastic bucket with a lip diameter of $255 \mathrm{~mm}$ ) was deployed in the field it received a thorough wash, first with tap and then with de-ionised water. In the field, each bucket was set into a solid styrene foam block which was firmly anchored to the soft soil. Rainwater was removed from these buckets only during times of no precipitation. All three would be attended to within one hour or, in the case of site 4, within two hours. Rainwater was decanted on-site into sterile $250 \mathrm{ml}$ plastic bottles. About $50-100 \mathrm{ml}$ of de-ionised water was used to wash the bucket and also decanted, to help assure the integrity of the next water sample and keep a running check in the event of possible contamination arising through the water collection procedure. In order to arrest biological degradation which might ot herwise alter the chemical composition, enough chloroform was added, in the laboratory, to each decanted water bottle, including wash water, to make up about a $10 \%$ solution.

Complete meteorological records were kept for the period of this study to help later correlation of rainfall events with subsequent salt concentrations for each site. These meteorological records are, strictly speaking, accurate only for site $I$ but can be extrapolated to other sites with caution. Subsequent chemical analysis was performed by the CSIRO Division of Atmospheric Research in Melbourne.

In all, $263250-\mathrm{ml}$ sample bottles were collected, representing about 43 litres of rainwater over a four-month period. The success of this project depended upon obtaining enough water samples, covering as many individual precipitation events as possible, to perform subsequently a statistically relevant and meaningful analysis of the data. (Note that the chemical analysis accuracy is given as $\pm 3.5 \%$ whilst rainwater volumes are accurate to $\pm 0.1 \mathrm{ml}$.)

TABLE 2

\section{Monthly mean rainfall data for site 1}

\begin{tabular}{|c|c|c|c|c|}
\hline Month & $\begin{array}{c}\text { Total } \\
\text { rainfall }\end{array}$ & $\begin{array}{l}\text { No. days } \\
\text { rainfall }\end{array}$ & $\begin{array}{l}\text { Approx. hrs } \\
\text { rainfall }\end{array}$ & $\begin{array}{c}\text { Average } \\
\text { rainfall rate } \\
\left(\mathrm{mmhr}^{-1}\right)\end{array}$ \\
\hline Dec 1985 & 23.8 & 9 & 54 & 0.441 \\
\hline Jan 1986 & 73.0 & 25 & 210 & 0.348 \\
\hline Feb 1986 & 84.8 & 18 & 174 & 0.487 \\
\hline Mar 1986 & 136.2 & 28 & 357 & 0.382 \\
\hline Apr 1986 & 41.4 & 9 & 117 & 0.354 \\
\hline
\end{tabular}




\section{ANALYSIS}

A full theoretical description of scavenging by convective diffusion of aerosol particles by cloud droplets is given in Mallis (1985) and will not be repeated here. However, the same mathematical symbols and definitions are retained.

A reasonable estimate of the scavenging coefficient, $\Lambda$, has been given by Pruppacher \& Klett (1980), taking into account both in- and below-cloud scavenging. $\Lambda$ is given by

$$
\Lambda \approx 4.2 \times 10^{-4} \mathrm{ER}^{0.79} \mathrm{sec}^{-1}
$$

where $\bar{E}$ is the characteristic collision frequency for drop-droplet interactions and $\mathrm{R}$ is the rain rate in $\mathrm{mmhr}^{-1}$. $\overline{\mathrm{E}}$ is taken to equal 0.83 , from Crandall $e t$ al. (1973). A nestimate of $R$ for site 1 is found from table 2 , where the total rainfall rate is calculated as a monthly mean. The total mean rainfall rate over the five months was found to be $\bar{R}=0.402 \mathrm{mmhr}^{-1}$, with a stand ard deviation of $0.060 \mathrm{mmhr}^{-1}$.

An estimate of the scavenged deposition rate, $\mathrm{Q}$, of $\mathrm{NaCl}$ in $\mathrm{kg} / \mathrm{ha} / \mathrm{yr}$ is given by

$$
\mathrm{Q}=\Lambda \mathrm{n}_{\mathrm{x}} \mathrm{t}_{1 / 2} \mathrm{~W}_{\mathrm{L}}^{-1} \mathrm{~A}
$$

where $A$ is a conversion factor $\left(\mathrm{kgcm}^{3} / \mathrm{ha} / \mathrm{yr}\right), \mathrm{n}_{\mathrm{x}}$ is a mean $\mathrm{NaCl}$ particle concentration $\left(\mathrm{cm}^{-3}\right), t_{1 / 2}$ is the half-life of $\mathrm{NaCl}$ particles and $\mathrm{W}_{\mathrm{L}}$ is the liquid water content of cloud $\left(\mathrm{gcm}^{-3}\right)$. Best estimates of $\mathrm{t}_{1 / 2}, \mathrm{n}_{\mathrm{x}}$ and $\mathrm{W}_{\mathrm{L}}$ for average conditions are $8.56 \times 10^{5}$ $\mathrm{sec}, 167 \mathrm{~cm}^{-3}$ and $0.6 \times 10^{-6} \mathrm{gcm}$ respectively. Only $\mathrm{n}_{\mathrm{x}}$ is considered to vary significantly over the three collection sites, and so $\Lambda, t_{1 / 2}$ and $W_{L}$ are considered constant in the ensuring analysis.

As determined earlier (Mallis 1985), it is possible to estimate the amount of in-cloud scavenging qualitatively, using equation (1). This was found to be about $\left(D^{1} \Rightarrow\right) 58 \mathrm{~kg} / \mathrm{ha} / \mathrm{yr}$ of $\mathrm{NaCl}$ deposited in precipitation. This value was estimated, using the above variable values of $n_{x}, t_{1 / 2}$ and $W_{L}$, and taking $R=R_{x}=0.401 \mathrm{mmhr}_{-1}$. Note that $R_{x}$ and $\bar{R}$ compare extremely favourably. Also calculated was the total expected amount of $\mathrm{NaCl}$ deposited due to in- and below-cloud scavenging. This was found to be about $\left(Q_{m}=\right) 411 \mathrm{~kg} / \mathrm{ha} / \mathrm{yr}$ for site 1. Having access to quantitative data, it is now possible to improve the original scavenging model and compare with actual observations as a test of its accuracy.

A new estimate of the actual in-cloud scavenging rate, $\mathrm{D}$, can be given by

$$
\mathrm{D}=\mathrm{D}^{\prime}\left(\overline{\mathrm{n}}_{\mathrm{A}}\right) /\left(\overline{\mathrm{n}}_{\mathrm{x}}\right)
$$

where $\bar{n}_{A}$ is an estimate of the average $\mathrm{NaCl}$ particle concentration at cloud altitudes and in region $\mathrm{A}$;

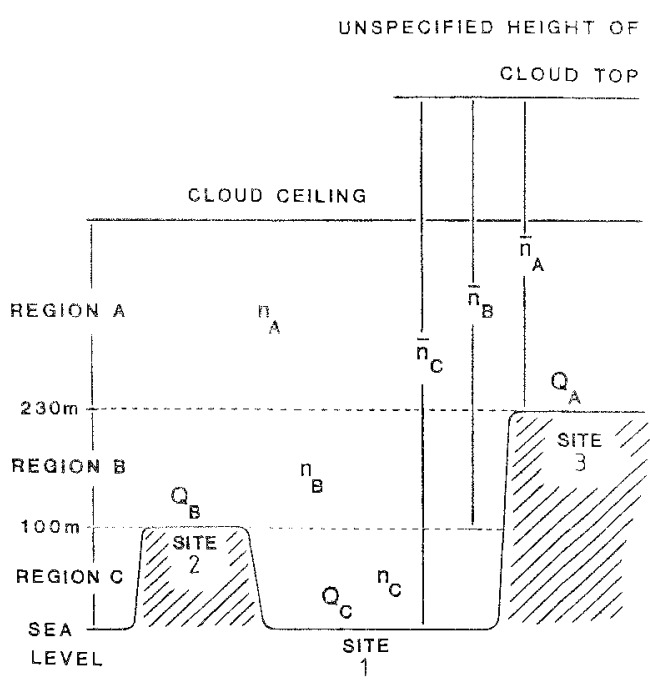

FIG. 2 - Schematic diagram of isthmus as viewed from west looking east, with regions $A, B$ and $C$ defined, along with relevant parameters.

similarly $\bar{n}_{B}$ and $\bar{n}_{C}$ are the averaged particle concentration values calculated within regions $B$ and $\mathrm{C}$, and regions $\mathrm{A}, \mathrm{B}$ and $\mathrm{C}$ respectively (fig. 2 indicates these regions). These averaged particle concentrations are given by

$$
\begin{aligned}
& \bar{n}_{A}=\bar{n}_{x}\left(P_{A} / Q_{A}\right) \\
& \bar{n}_{B}=n_{x}\left[\left(P_{B}-D\right) / Q_{B}\right] \\
& \bar{n}_{C}=n_{x}\left[\left(P_{C}-D\right) / Q_{C}\right]
\end{aligned}
$$

where $Q_{A}, Q_{B}$ and $Q_{C}$ are the estimated total deposition rates due to scavenging of $\mathrm{NaCl}$ in precipitation within regions $\mathrm{A}, \mathrm{B}$ and $\mathrm{C}$ respectively; also $P_{A}, P_{B}$ and $P_{C}$ are the actual deposition rates, as measured at the bottom of regions $A, B$ and $C$ respectively. $P_{A}, P_{B}$ and $P_{C}$ values are determined in the next section.

After making due allowance for differing rainfall rates within each region, $Q_{A}, Q_{B}$ and $Q_{c}$ can be estimated from

$$
\begin{aligned}
& Q_{A}=Q_{M}\left(R_{x} / R_{A}\right)^{0.79} \\
& Q_{B}=Q_{M}\left(R_{x} / R_{B}\right)^{0.79} \\
& Q_{C}=Q_{M}\left(R_{x} / R_{C}\right)^{0.79}
\end{aligned}
$$

where $R_{A}, R_{B}$ and $R_{C}$ are the estimated rainfall rates for regions $A, B$ and $C$ respectively. Table 3 lists five separate collections made at all sites. Total volume of rainwater plus the percentage difference between sites 2 and 3 with respect to site 1 is given. 


\section{TABLE 3}

Volume of rainwater collected from all available sites at approximately the same time

\begin{tabular}{lccc}
$\begin{array}{l}\text { Collection } \\
\text { date/period* }\end{array}$ & $\begin{array}{c}\text { Collection } \\
\text { site }\end{array}$ & $\begin{array}{c}\text { Volume } \\
\text { rainwater } \\
\text { collected } \\
(\mathbf{m l})\end{array}$ & $\begin{array}{c}\text { Percentage } \\
\text { difference } \\
\text { WRT site 1 }\end{array}$ \\
\hline 29 Dec 1985 & 1 & 284.6 & - \\
(2) & 2 & 369.3 & 29.8 \\
2 Jan 1986 & 1 & 381.6 & - \\
(3) & 2 & 476.0 & 24.7 \\
& 3 & 548.0 & - \\
9 Jan 1986 & 1 & 167.2 & 39.6 \\
(6) & 2 & 233.4 & 51.3 \\
& 3 & 252.9 & - \\
13 Jan 1986 & 1 & 159.1 & 31.0 \\
(4) & 2 & 170.9 & - \\
23 Feb 1986 & 3 & 208.5 & 11.5 \\
(12) & 1 & 3344.6 & 17.2 \\
\hline
\end{tabular}

* Numbers in parentheses indicate sample period, in days, over which collections were made.

These mean percentage differences of sites 2 and 3 are listed in table 4 , along with their estimated mean rainfall rate. It is readily observed that $R_{A}>$ $\mathrm{R}_{\mathrm{B}}>\mathrm{R}_{\mathrm{C}}$ on average.

Using the following equations, estimates of particle concentrations within regions $\mathrm{A}, \mathrm{B}$ and $\mathrm{C}$ respectively are

$\mathrm{n}_{\mathrm{A}}=\mathrm{n}_{\mathrm{A}}$

$\bar{n}_{\mathrm{B}}=\left[\mathrm{n}_{\mathrm{A}}\left(\mathrm{P}_{\mathrm{A}}-\mathrm{D}\right)+\mathrm{n}_{\mathrm{B}}\left(\mathrm{P}_{\mathrm{B}}-\mathrm{P}_{\mathrm{A}}\right)\right] / \mathrm{P}_{\mathrm{B}}-\mathrm{D}$

$\bar{n}_{C}=\left[n_{A}\left(P_{A}-D\right)+n_{B}\left(P_{B}-P_{A}\right)+n_{C}\left(P_{C}-P_{B}\right)\right] / P_{C}-D$

Note that the RHS of equations (10) and (11) are, in fact, weighted means used in determining $\overline{\mathrm{n}}_{\mathbf{B}}$ and

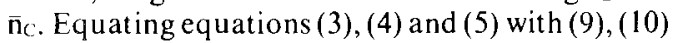
and (11) respectively, and substituting for $\mathrm{Q}_{\mathrm{A}}, \mathrm{Q}_{\mathrm{B}}$ and $Q_{C}$ from equations $(6),(7)$ and $(8)$ respectively, solutions for $n_{A}, n_{B}$ and $n_{C}$ can be found. Table 5 summarises these findings. Note that, although $n_{C} / n_{A}=1 / 5.9$ and $n_{B} / n_{A}=1 / 3.2$, coincidentally $P_{A} / P_{C}=1 / 6.5$ and $P_{A} / P_{B}=1 / 3.7$. The estimated in-cloud $\mathrm{NaCl}$ deposition rate, $\mathrm{D}$, is calculated from equation (1) and is found to be $69.3 \mathrm{~kg} / \mathrm{ha} / \mathrm{yr}$. Table 6 lists the volume of rainwater collected at site 1 and the rainfall amount as recorded by the Bureau of Meteorology rain gauge for the same time interval. Also listed is the calibration ratio, $r$, of rainwater collected to rainfall measured. The relative constancy of this ratio over the 23 collections is reasonably good, considering that Macquarie Island experiences much wind, making precipitation collections difficult even at the best of times. Although only site 1 had a rain gauge, the calibration ratio is taken to be valid for all collection sites. The mean value of $r$ was found to be $45.9 \mathrm{ml} / \mathrm{mm}$, with a standard deviation of $7.8 \mathrm{ml} / \mathrm{mm}$

\section{TABLE 4}

Estimated mean rainfall rates for sites 1, 2 and 3

\begin{tabular}{lcc} 
Site & \multicolumn{2}{c}{ Rainfall rate* $^{*}$} \\
\cline { 2 - 3 } & $\begin{array}{c}\text { Mean percentage } \\
\text { difference } \\
\text { WRT site }\end{array}$ & $\begin{array}{c}\text { Estimated mean } \\
\mathbf{R} \\
\left(\mathbf{m m h r}^{-1}\right)\end{array}$ \\
\hline 1 & - & $0.402(0.060)$ \\
2 & $25.4(13.5)$ & $0.504(0.456)$ \\
3 & $42.0(10.2)$ & $0.571(0.443)$ \\
\hline
\end{tabular}

* Numbers in parentheses give one standard deviation about the mean. 
TABLE 5

Summary of deposition and rainfall rate, and mean particle concentration for various althtudes over Macquarie Island

\begin{tabular}{|c|c|c|c|}
\hline Region & $\begin{array}{c}\text { Total } \mathrm{NaCl} \\
\text { deposited } \\
\text { of region base } \\
\text { p } \\
(\mathrm{kg} / \mathrm{hg} / \mathrm{yr})\end{array}$ & 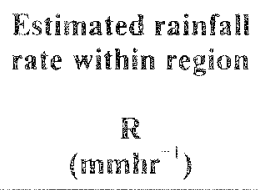 & $\begin{array}{c}\text { Cstimated partide } \\
\text { concerutration } \\
\text { whithin region } \\
\text { n } \\
\left(\mathrm{cm}^{-3}\right)\end{array}$ \\
\hline $\begin{array}{l}\mathrm{A} \\
\mathrm{B} \\
\mathrm{C}\end{array}$ & $\begin{array}{r}370(205) \\
655(798) \\
2423(2539)\end{array}$ & $\begin{array}{l}0.571(0.443) \\
0.504(0.456) \\
0.402(0.060)\end{array}$ & $\begin{array}{c}200(121) \\
376(400) \\
1182(1198)\end{array}$ \\
\hline
\end{tabular}

* Numbers in parentheses indicate standard deviation of variable.

TABLE 6

\section{Summary of rainwater and rainfall data} for site 1

\begin{tabular}{lrrc} 
Date & $\begin{array}{c}\text { Rainwater } \\
\text { collected } \\
(\mathbf{m})\end{array}$ & $\begin{array}{c}\text { Rainfall } \\
\text { recorded } \\
(\mathbf{m m})\end{array}$ & $\begin{array}{c}\text { Calibration } \\
\text { ratio, } \mathbf{r} \\
(\mathbf{m l} / \mathbf{m m})\end{array}$ \\
\hline 18 Dec 1985 & 683.5 & 15.2 & 45.0 \\
18 Dec 1985 & 163.1 & 3.3 & 49.4 \\
27 Dec 1985 & 92.6 & 2.1 & 44.1 \\
29 Dec 1985 & 302.6 & 6.8 & 44.5 \\
30 Dec 1985 & 300.2 & 6.2 & 48.4 \\
31 Dec 1985 & 53.2 & 1.4 & 38.1 \\
2 Jan 1986 & 326.3 & 6.0 & 51.0 \\
3 Jan 1986 & 434.0 & 9.8 & 44.3 \\
9 Jan 1986 & 167.2 & 6.2 & 27.0 \\
13 Jan 1986 & 159.1 & 3.6 & 44.2 \\
17 Jan 1986 & 898.0 & 15.6 & 57.6 \\
1 Feb 1986 & 760.8 & 29.0 & 26.2 \\
6 Feb 1986 & 409.6 & 8.6 & 47.6 \\
11 Feb 1986 & 226.1 & 6.0 & 37.7 \\
23 Feb 1986 & 3728.9 & 67.6 & 55.2 \\
3 Mar 1986 & 2130.9 & 50.0 & 42.6 \\
7 Mar 1986 & 846.1 & 16.6 & 51.0 \\
9 Mar 1986 & 133.4 & 2.6 & 51.3 \\
10 Mar 1986 & 255.5 & 5.0 & 51.1 \\
25 Mar 1986 & 2359.4 & 51.0 & 46.3 \\
29 Mar 1986 & 752.9 & 13.8 & 54.6 \\
8 Apr 1986 & 1879.7 & 39.9 & 47.1 \\
9 Apr 1986 & 220.0 & 4.3 & 51.2 \\
Mean & & & 45.9 \\
Standard & & & \\
deviation & & & 7.8 \\
\hline & & & \\
\hline
\end{tabular}

\section{TABLE 7}

\section{$\mathrm{NaCl}$ concentrations collected from all available sites at approximately the same time}

\begin{tabular}{lccc}
$\begin{array}{l}\text { Collection } \\
\text { date/period* }\end{array}$ & $\begin{array}{c}\text { Collection } \\
\text { site }\end{array}$ & $\begin{array}{c}\text { [NaCl] } \\
\text { (mm) }\end{array}$ & $\begin{array}{c}\text { Percentage } \\
\text { difference } \\
\text { WRT site I }\end{array}$ \\
\hline 29 Dec 1985 & 1 & 1520 & - \\
(2) & 2 & 853 & -43.9 \\
2 Jan 1986 & 1 & 5819 & - \\
(3) & 2 & 1279 & -78.0 \\
& 3 & 1393 & -76.1 \\
9 Jan 1986 & 1 & 2964 & - \\
(6) & 2 & 588 & -80.2 \\
& 3 & 696 & -76.5 \\
13 Jan 1986 & 1 & 1166 & - \\
(4) & 2 & 553 & -52.6 \\
& 3 & 540 & -53.7 \\
23 Feb 1986 & 1 & 1606 & - \\
(12) & 2 & 743 & -53.7 \\
& 4 & 319 & -80.1 \\
\hline
\end{tabular}

* Numbers in parentheses indicate sample period, in days, over which collections were made.

Note that converting from particle concentration in $\mathrm{mg} / \mathrm{l}$ to $\mathrm{kg} / \mathrm{ha} / \mathrm{yr}$ simply requires multiplying concentration values by the conversion factor $\mathrm{C}$, where

$$
\begin{aligned}
\mathrm{C}= & \mathrm{r}(\mathrm{ml} / \mathrm{mm}) \times 10^{-3}(\mathrm{l} / \mathrm{ml}) \times \rho(\mathrm{mm} / \mathrm{yr}) \times \\
& 10^{4}\left(\mathrm{~m}^{2} / \mathrm{ha}\right) \times 10^{-6}(\mathrm{~kg} / \mathrm{mg}) \times \mathrm{a}^{-1}\left(\mathrm{~m}^{-2}\right)
\end{aligned}
$$

where $\rho$ is the yearly rainfall rate and $a$ is the collection container area of $0.0511 \mathrm{~m}^{2}$. C needs to be determined for each site, since $\rho$ differs. 
TABLE 8

\section{Ionic concentrations in rainwater from all collection sites}

\begin{tabular}{|c|c|c|c|c|}
\hline \multirow{2}{*}{$\begin{array}{l}\text { Collection } \\
\text { date }\end{array}$} & \multicolumn{4}{|c|}{$\left[\mathrm{Cl}^{-}\right] /\left[\mathrm{SO}_{4}^{2}\right]$} \\
\hline & Site 1 & Site 2 & Site 3 & Site 4 \\
\hline $18 \mathrm{Dec} 85$ & 17.1 & & & \\
\hline 18 Dec 85 & 17.8 & & & \\
\hline 19 Dec 85 & & 18.5 & & \\
\hline 27 Dec 85 & 19.1 & 16.2 & & \\
\hline 29 Dec 85 & 19.2 & 18.3 & 18.2 & \\
\hline 30 Dec 85 & 19.2 & 20.6 & 18.8 & \\
\hline $3 !$ Dec 85 & 19.0 & & & \\
\hline $2 \operatorname{Jan} 86$ & 26.1 & 18.8 & 18.5 & \\
\hline 3 Jan 86 & 18.4 & 14.3 & 12.5 & \\
\hline 9 Jan 86 & 19.4 & 17.1 & 16.7 & \\
\hline $13 \mathrm{~J}$ an 86 & 18.0 & 16.1 & 16.4 & \\
\hline $17 \mathrm{Jan} 86$ & 17.8 & & & \\
\hline $18 \mathrm{Jan} 86$ & & 16.8 & & \\
\hline 1 Feb 86 & 19.4 & & & \\
\hline 2 Feb 86 & & 18.4 & & \\
\hline 6 Feb 86 & 18.2 & & & \\
\hline 7 Feb 86 & & & 17.0 & \\
\hline 11 Feb 86 & 18.8 & 17.7 & & \\
\hline 13 Feb 86 & & & & 17.8 \\
\hline 23 Feb 86 & 19.1 & 17.7 & & 15.7 \\
\hline 3 Mar 86 & 18.9 & & & \\
\hline 4 Mar 86 & & 19.6 & & \\
\hline 7 Mar 86 & 19.6 & & & \\
\hline 9 Mar 86 & 20.0 & & & \\
\hline 10 Mar 86 & 20.4 & & & \\
\hline 16 Mar 86 & & 19.4 & & \\
\hline 25 Mar 86 & 19.9 & & & \\
\hline $29 \operatorname{Mar} 86$ & 19.8 & 21.2 & & \\
\hline 3 Apr 86 & & 19.0 & & \\
\hline 8 Apr 86 & 19.3 & & & \\
\hline 9 Apr 86 & 19.4 & 19.4 & & \\
\hline
\end{tabular}

Table 7 lists mean $\mathrm{NaCl}$ concentrations for various sites of rainwater samples spanning concurrent periods of time. The collection date and site and percentage difference of $[\mathrm{NaCl}]$ with respect to site 1 are also given. Note that, on average, the percentage difference and standard deviations of [ $\mathrm{NaCl}]$ between sites 1 and 2 , and sites 1 and 3 are $(61 \%, 16.5 \%)$ and $(68.8 \%, 13.1 \%)$ respectively. Site 1 has consistently higher $\mathrm{NaCl}$ concentrations than sites 2 and 3. This is to be expected anyway, because the scavenging coefficient, $A$, decreases with increasing altitude since it is directly proportional to the vertical sea-salt concentration, as shown in table 5 .
TABLE 9

\section{$\mathrm{NaCl}$ concentration in individual water samples for all collection sites}

Collection Equivalent $\mathrm{NaCl}$ deposited in rain date (mg/l)

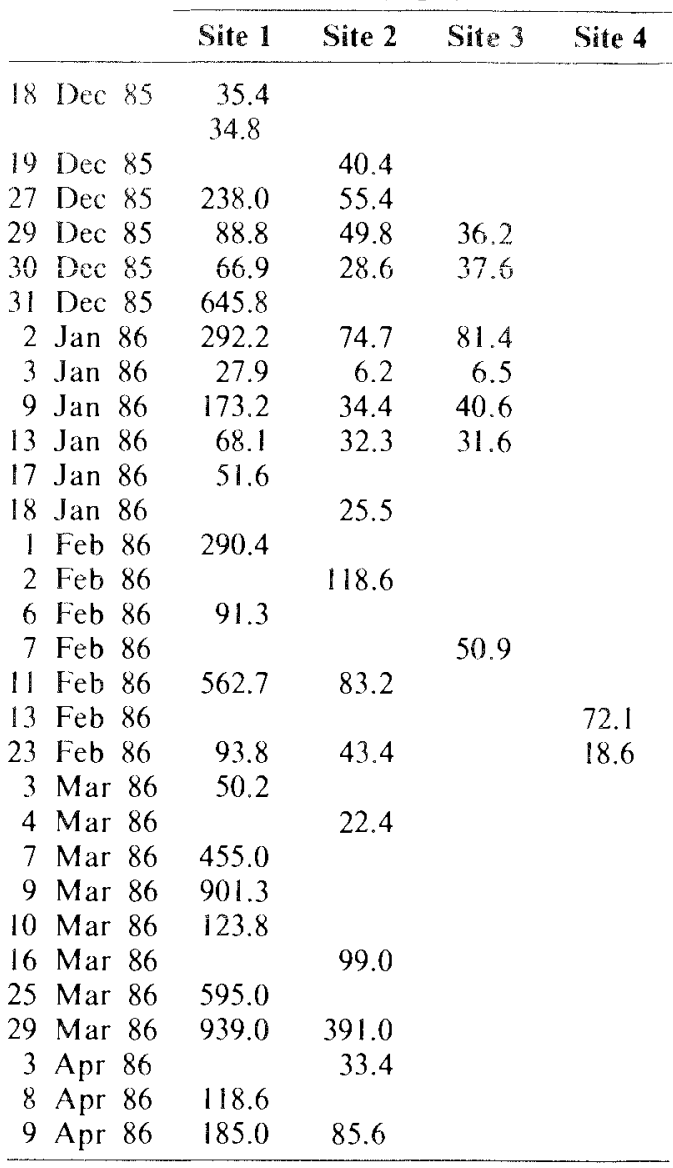

If $n_{x}$ is now replaced by $n_{x}{ }^{\prime}=\left(n_{A}+n_{H}+n_{C}\right) / 3$ and a recalculation of $Q_{M}$ is made, then a more accurate theoretical estimate of $Q_{m}$ can be made, based on a better estimate for $n . n_{x}{ }^{\prime}$ is taken to be the mean $\mathrm{NaCl}$ particle concentration over site 1 , averaged over regions $\mathrm{A}, \mathrm{B}$ and $\mathrm{C}$, a simple assumption which later proves to be a good estimate. Let $Q_{m}^{\prime}$ stand for this new theoretical estimate, which can be simply found from

$$
\mathrm{Q}_{\mathrm{m}}{ }^{\prime}=\mathrm{Q}_{\mathrm{m}}\left(\mathrm{n}_{\mathrm{x}}{ }^{\prime} / \mathrm{n}_{\mathrm{x}}\right)
$$

$\mathrm{Q}^{\prime}{ }^{\prime}$ and $\mathrm{n}_{\mathrm{x}}{ }^{\prime}$ become equal to $1441 \mathrm{~kg} / \mathrm{ha} / \mathrm{yr}$ and $619 \mathrm{~cm}^{-3}$ respectively. $\mathrm{Qm}_{\mathrm{m}}$ ' is now the new theoretically derived value of $\mathrm{NaCl}$ deposition rate in 
precipitation at site 1 . It will be demonstrated in the next section that this compared favourably with actual measurements.

\section{RESULTS}

Unfortunately, due to an unknown and unspecified problem with the chemical analysis of rainwater, it was not possible to obtain consistent $\left[\mathrm{Na}^{+}\right]$values. However, $[\mathrm{Cl}]$ and $\left[\mathrm{SO}_{4}^{2-}\right]$ values were successfully determined. To demonstrate whether $\mathrm{NaCl}$ deposited in precipitation is marine derived, the $\mathrm{ratio}\left[\mathrm{Cl}^{-}\right]$to $\left[\mathrm{SO}_{4}^{2}\right]$ was calculated and compared to the known ratio for seawater, a constant ratio of 19.3 (Millero 1974). Table 8 lists recovery dates, collection sites and the ratio $\left[\mathrm{Cl}^{-}\right]$to $\left[\mathrm{SO}_{4}^{2-}\right]$ for all water samples used in the ensuing analysis. For sites 1,2 and 3 the mean $\left[\mathrm{Cl}^{-}\right]$to [ $\mathrm{SO}_{4}^{2}$ ] ratio and standard deviation values are $(19.3,1.7),(18.2,1.7)$ and $(16.9,2.1)$ respectively. Sulphates being of a higher molecular weight would be expected to have a different scavenging coefficient dependence with altitude. In fact, the trend appears to be that the ratio $[\mathrm{Cl}]$ to $\left[\mathrm{SO}_{4}^{2-}\right]$ decreases with increasing altitude. However, the result appears to be consistent with Evans'(1970), Jenkin's (1972) and Croome's (1984) conclusions, in that $\mathrm{NaCl}$, at least, is marine derived in precipitation over Macquarie Island. Table 9 lists date, collection site and [ $\mathrm{NaCl}]$ for each sample collected. Much variability in concentration is evident and is directly atributed to local weather conditions, such as humidity and wind speed. This variability is not examined in this study, as not enough is known about these conditions at sites 2,3 and 4 . Mean values of [ $\mathrm{NaCl}]$, as collected for each site, are listed in table 10 along with the equivalent deposition rate for $\mathrm{NaCl}$.

It was calculated by Evans (1970) that 24000 $\mathrm{kg} / \mathrm{ha} / \mathrm{yr}$ of $\mathrm{NaCl}$ are deposited in precipitation over site 1 , and similarly 7999 and $565 \mathrm{~kg} / \mathrm{ha} / \mathrm{yr}$ of $\mathrm{NaCl}$ over site 2 and site 3 respectively, by Jenkin (1972). These amounts for sites 1 and 2 are in gross disagreement with those obtained in the present study. This discrepancy is sither due to inaccurate chemical analysis or faulty collection procedures. For example, Evans does not describe the procedure used in decanting rainwater samples, nor if they were fixed against degradation. It is quite possible that either too few samples were collected and/or analysed or that too many rain events occurred before a collection was made. Averaging of $[\mathrm{NaCl}]$ for too few rainwater samples may indeed have revealed such a high deposition rate. The variability in measured deposition rates in this study has been shown to be quite high, but it is not high enough to account for a tenfold variation in Evans' data for site 1 . If a collection container is left unserviced for a long time it is quite possible that some evaporation of water can occur, due to wind and sun action; also dry salt particles can attach themselves to the collection container during non-precipitation

\section{TABLE 10}

\section{Mean $\mathrm{NaCl}$ concentration from all samples for each collection site and their equivalent deposition rates, along with previously determined deposition rates by Evans $(\mathbf{E})$ and Jenkin $(\mathbf{J})^{*}$}

\begin{tabular}{|c|c|c|c|c|}
\hline \multirow[t]{2}{*}{$\begin{array}{l}\text { Collection } \\
\text { site }\end{array}$} & \multirow{2}{*}{$\begin{array}{l}\text { Number of } \\
\text { rainwater } \\
\text { collections }\end{array}$} & \multirow[t]{2}{*}{$\begin{array}{l}{[\mathrm{NaCl}]} \\
(\mathrm{mg} / 1)\end{array}$} & \multicolumn{2}{|c|}{$\begin{array}{l}\text { Calculated deposition rate of } \mathrm{NaCl} \\
(\mathrm{kg} / \mathrm{ha} / \mathrm{yr})\end{array}$} \\
\hline & & & Mallis & Evans and Jenkin \\
\hline 1 & 23 & $\begin{array}{l}266.5 \\
(279.5)\end{array}$ & $\begin{array}{l}2423 \\
(2539)\end{array}$ & $\begin{array}{l}24016(\mathrm{E}) \\
{[13]}\end{array}$ \\
\hline 2 & 17 & $\begin{array}{l}72.0 \\
(87.6)\end{array}$ & $\begin{array}{l}654.5 \\
(798)\end{array}$ & $\begin{array}{l}7999(J) \\
{[66]}\end{array}$ \\
\hline 3 & 7 & $\begin{array}{l}40.7 \\
(22.5)\end{array}$ & $\begin{array}{l}370 \\
(205)\end{array}$ & $\begin{array}{l}565(\mathbf{J}) \\
{[50]}\end{array}$ \\
\hline 4 & 2 & $\begin{array}{l}45.4 \\
(-)\end{array}$ & $\begin{array}{l}413 \\
(-)\end{array}$ & $630(E)$ \\
\hline
\end{tabular}

* Numbers in square brackets give the known number of continuous days over which rainwater was collected. Parentheses contain the standard deviation of the mean. No standard deviations are given for site 4 , because only two samples were collected, and so no statistical significance could be claimed. 
periods. Either possibility, or a combination, can lead counrealistically high levels of $\mathrm{NaCl}$; hence, in the present study, the collection of rainwater samples every few days from all sites. Thus, it is claimed that data collected by the present study and listed in table 10 are much more representative of actual deposition rates than Evans" and some of Jenkin's data. Evans" data are also questionable on the grounds that Millero (1974) gives average world seawater $[\mathrm{NaCl}]$ as $30120 \mathrm{mg} / \mathrm{l}$. This compares with $2674 \mathrm{mg} / 1$ from Evans' data for site 1, which is some $9 \%$ of that of seawater. This figure seems quite large and unrealistic.

\section{CONCLUSION}

As a result of the present studies, it is claimed that deposition of scavenged airborne $\mathrm{NaCl}$ particles over Macquarie Island in precipitation is almost entirely due to dry sea salt and not sea spray. Although it cannot be explicitly proven that this finding is valid, it is encouraging that the theoretically predicted deposition rate of $1441 \mathrm{~kg} / \mathrm{ha} / \mathrm{yr}$ falling on site 1 is $60 \%$ of that actually recorded, namely $2423 \mathrm{~kg} / \mathrm{ha} / \mathrm{yr}$. Considering that the observed standard deviation was $2539 \mathrm{~kg} / \mathrm{ha} / \mathrm{yr}$, the theoretically derived value seems an acceptable figure. It appears that Evans' (1970) and Jenkin's (1972) data previously contributed to false inferences regarding $\mathrm{NaCl}$ scavenging. It is now concluded that scavenging of airborne (dry) $\mathrm{NaCl}$ particles can alone successfully account for the total $\mathrm{NaCl}$ deposited due to in- and below-cloud scavenging over Macquarie Island, and there is no need to suppose that scavenging of sea spray is responsible for any major component of the total salt budget. Experimental data, collected to test previous theoretical calculations made of this problem, seem to verify the above conclusion.

\section{ACKNOWLEDGEMENTS}

Permission to visit Macquarie Island was granted by the Macquarie Island Advisory Committee, whilst logistic support was provided by the Antarctic Division during the 1985-86 summer season. Their efforts in supporting this project are gratefully acknowledged.

Chemical analysis was carried out at CSIRO Division of Atmospheric Research, Aspendale, and at the Australian Government Analytic Laboratories, Kingston, under the direction of $\mathrm{Dr}$ Greg Ayers of CSIRO. His assistance and helpful advice throughout the course of this project is particularly acknowledged.

\section{REFERENCES}

CRANDALL, W.K., MOLENKAMP, C.R., WILLIAMS, A.L., FULK, M.M., LANGE, R. \& KNOX, J.B., 1973: Res. Rep. UCRL-75896. Lawrence Livermore Laboratory, California.

CROOME, R., 1984: Limnological studies on Macquarie Island. Tasm. Nat., 78: 26-27.

EVANS, A.J., 1970: Some aspects of the ecology of a calanoid copepod, Pseudoboeckella brevicaudatla Brady 1875, on a subantarctic island. ANARE Rep., 110

JENKIN, J.F., 1972: Studies on plant growth in a subantarctic environment. Unpublished Ph.D. thesis, University of Melbourne.

MALLIS, M., 1985: A qualitative investigation into scavenging of airborne sea salt over Macquarie Island. $A N A R E$ Res. Noles, 26.

MILLERO, F.J., 1974: The physical chemistry of seawater. Ann. Rev, Earlh Planet. Sci., 2: 101-150.

PRUPPACHER, H.R \& KLETT, J.D., 1980: MICROPHYSICS OF CLOUDS AND PRECIPITA$T I O N$. D. Reidel, Holland.

(accepted 16 November 1987) 